\title{
Evaluation of Thiopentone Sodium, Propofol and Midazolam for Modified Electro Convulsive Therapy
}

\author{
Harsh Kasliwal' ${ }^{1}$, Vipin Kumar Varshney ${ }^{2}$, M. M. Neema ${ }^{3}$ \\ ${ }^{1}$ Assistant Professor, Department of Anaesthesiology, R D Gardi Medical College Ujjain, ${ }^{2}$ Assistant Professor, Department of Anaesthesiology, Teerthanker \\ Mahaveer Medical College Moradabad (U.P), ${ }^{3}$ Professor \& Head, Department of Anesthesiology, R.D. Gardi Medical College, Ujjain.
}

\section{Abstract}

Background: Modified Electroconvulsive therapy (MECT), is evidence based, safe and established treatment for varieties of psychiatric diseases that includes acute mania, major depressive disorder, schizophrenia, suicidal tendency and many more conditions. Government of India and world health organization has mandated use of sedative / anesthetic drug to make MECT acceptable method of treatment. MECT is administered under anesthesia to control acute cardiovascular, cerebrovascular and musculoskeletal changes occurring subsequent to delivery of electric current across the cerebral cortex. This also prevents respiratory and traumatic complications. Subjects and Methods: In the present clinical observational study we analyzed 113 MECT administrations for evaluating suitability of thiopentone sodium, propofol and midazolam with succinyl choline chloride; on 45 patients belonging to ASA grade II with no associated systemic diseases. Results: We observed the induction characteristics, induction and recovery time, associated changes in hemodynamic parameters during and after procedure, duration and energy required to induce muscular convulsions and changes in serum potassium level. Our observations indicates that induction was quicker with propofol than with thiopentone $43.67 \pm 9.13 \mathrm{v} / \mathrm{s} 61.31 \pm 15.58$ seconds and recovery time was also quicker with propofol than thiopentone $518.73 \pm 69.67 \mathrm{v} / \mathrm{s} 595.25 \pm 112.68$ seconds. Only on one occasion in thiopentone group induction was turbulent. Acute but short lasting changes in heart rate, systolic, diastolic and mean arterial pressure was observed in both thiopentone and propofol groups. The energy requirement was less than 100 joules on 34 sittings in thiopentone group while in propofol group it was observed on 47 sittings. In thiopentone group on 17 occasion energy required were more than 100 joules and 5 sittings in propofol group. There was transient elevation of mean serum potassium of $0.55 \mathrm{mEq} / \mathrm{lit}$ after MECT in all patients. Midazolam did not produce satisfactory condition in dose of $5 \mathrm{mg}$ and needed thiopentone supplement on 10 occasions. Conclusion: The findings allowed us to conclude that both thiopentone and propofol along with subparalytic dose of succinyl choline chloride produced satisfactory conditions for MECT sittings without complications. However propofol provided quick induction and recovery and lesser energy requirement.

Keywords: MECT, thiopentone, propofol midazolam anesthesia.

Corresponding Author: Dr. Vipin Kumar Varshney, Assistant Professor, Department of Anaesthesiology, Teerthanker Mahaveer Medical College Moradabad (U.P).

Received: February 2019

Accepted: March 2019

\section{Introduction}

In early 1900s, Meduna, Father of convulsive therapy for the cure of psychiatric diseases like acute mania, schizophrenia and depressive disorders used chemicals (Camphor, leptazol, insulin etc) to induce convulsions in his patients. His assumptions were based on principle of biological antagonism that, epilepsy and schizophrenia do not coexist. $^{[1]}$

Later on Ugo cerelleti and Luci Binni (1939) after animal and human experiments established that convulsions can be easily and reliably induced by application of appropriate strength of electric current to the cerebral cortex and called this method as "Electro Convulsive Therapy" (ECT). ${ }^{[2]}$

Direct application of current to the cerebral cortex results in acute and short lasting changes in body physiology which involves almost all body systems including cardiovascular, cerebrovascular, muscle injuries, bone fractures and joint dislocations and accidental airway choking is also reported. ${ }^{[1]}$

It is not a pleasant site to look at frothing, convulsing patient held by robust persons to avoid injuries.

Electroconvulsive therapy is an effective physical treatment supported by evidences for treating variety of psychiatric ailments as drug resistant major depressive disorder, schizophrenia, acute mania, suicidal tendency, endogenous depression and many more clinical conditions. ${ }^{[3]}$

Because MECT is a short procedure of several minutes that causes involvement of almost all body systems after delivery of electric current; therefore anesthesia requirements for electroconvulsive therapy are unique and intended towards quick induction and recovery, attenuation of cardiovascular, cerebrovascular and musculoskeletal changes and avoidance of physical injuries and upper airway choking. Therefore while planning sedation/anesthesia for conducting MECT these objectives are to be kept in mind besides availability of 
resuscitation facilities. ${ }^{[1,3]}$

Proper conduct of ECT in operation theatre with anesthesia machine, resuscitation facilities and the use of sedatives or anesthetics is called modified electroconvulsive therapy (MECT).

Government of India (2010) and World Health Organization (1960) have mandated the use of some form of sedation or anesthesia to make ECT safe and acceptable procedure for the patients.

\section{Subjects and Methods}

- The present study was conducted on 45 patients divided in three groups as Thiopentone group (group-A), Propofol group (group-B), and Midazolam group (group-C), who received multiple sittings of MECT after approval of institutional ethics committee.

- Informed consent of blood relative was obtained and was instructed to observe that patient does not take any thing by mouth at least for 6 hours before the procedure.

- Antipsychotic medication was allowed to continue

- The observations were made on 113 sittings.

- In the operating room intravenous drip with normal saline was setup and multipara monitor applied for continuous monitoring of HR, ECG, SpO2, NIBP.

- All patients received Injection Atropine sulphate $0.6 \mathrm{mg}$ intravenously along with pre-oxygenation for 5 minutes before induction of anesthesia.

- Patients received either thiopentone sodium, (Max. dose $250 \mathrm{mg}$ ) Group A, propofol (Max. dose $80 \mathrm{mg}$ ) Group B or midazolam (Max. dose $5 \mathrm{mg}$ ) Group $\mathrm{C}$ with sub paralytic dose of succinyl choline chloride $(50 \mathrm{mg})$.

- After relaxation, psychiatrist was allowed to deliver electric current trans-cutaneously across cerebral cortex.

- Assisted breathing with $100 \%$ oxygen after delivery of electric current till the return of adequate rate and depth of spontaneous breathing and monitored continuously

- The patients shifted to recovery room after the patients were conscious with stable vitals and responding to verbal commands for further observation.

- On every MECT sitting patient received the same induction agent.

- Patients were monitored continuously on multipara for ECG, NIBP, SpO2 and heart rate during the entire procedure and continued with similar observations in recovery room till patient met the discharge criteria.

- Patients were shifted to their wards with necessary instructions.

\section{$\underline{\text { Statistical Method }}$}

- Continuous Numeric Data: Presented as Mean with standard deviation.

- Significance of observations analyzed by independent sample ' $t$ ' test.

- Significance limit: $\mathrm{P}<0.05$

- Complication Rate \& ratio presented as number of patients exhibiting and significance was found by chi square test.

- Observations presented as graphs and line diagram.

Results

We are presenting our observations made on 113 MECT sittings on 45 patients of physical status II as per American society of anesthesiologists' classification of physical status. All study subjects were free from concurrent systemic cardiovascular, cerebrovascular or other diseases.

[Table 1] shows the demographic profile and mean number of MECT sittings with each study drug

Table 1: ?
\begin{tabular}{|l|l|l|l|}
\hline Parameter & Group A & Group B & Group C \\
\hline $\begin{array}{l}\text { Mean age of } \\
\text { patients (in yrs.) }\end{array}$ & 32.4 & 28.2 & 29.0 \\
\hline Male : Female & $11: 9$ & $14: 6$ & $3: 2$ \\
\hline $\begin{array}{l}\text { Mean number of } \\
\text { MECT sittings per } \\
\text { patient }\end{array}$ & 2.50 & 2.55 & 2.0 \\
\hline
\end{tabular}

[Table 2] shows the induction characteristic, induction and recovery time with Thiopentone, propofol and midazolam. It was smooth on all sittings except on one occasion (less than $1 \%$ ) in thiopentone group. However midazolam in dose of 5 $\mathrm{mg}$ intravenously did not produce smooth induction on all 10 sittings and required supplement dose of thiopentone $100-$ $150 \mathrm{mg}$ to administer. Use of midazolam was dropped for further sittings as objected by psychiatrist.

Mean induction time was shorter with propofol (43.67 seconds) as compared with Thiopentone (61.47 seconds), the change is statistically highly significant. Induction time was calculated as time from the injection of drug till loss of verbal contact. Both induction and recovery was quicker with propofol than with thiopentone (highly significant value). The mean recovery time in propofol group $(518.73 \pm 69.67$ seconds) was shorter than with thiopentone (595.25 \pm 112.68 seconds) which was highly significant.

Table 2:
\begin{tabular}{|l|l|l|l|}
\hline $\begin{array}{l}\text { Induction } \\
\text { character }\end{array}$ & $\begin{array}{l}\text { Thiopentone } \\
\text { group }\end{array}$ & $\begin{array}{l}\text { Propofol } \\
\text { group }\end{array}$ & $\begin{array}{l}\text { Midazolam } \\
\text { group }\end{array}$ \\
\hline Smooth & 50 & 52 & 00 \\
\hline Turbulent & 01 & 00 & 10 \\
\hline $\begin{array}{l}\text { Mean } \\
\text { induction time }\end{array}$ & $\begin{array}{l}61.47 \pm 15.58 \\
\text { seconds }\end{array}$ & $\begin{array}{l}43.67 \pm 9.13 \\
\text { seconds }\end{array}$ & $\begin{array}{l}\mathrm{P}=,<0.01 \\
\text { (HS) }\end{array}$ \\
\hline $\begin{array}{l}\text { Mean } \\
\text { recovery time }\end{array}$ & $\begin{array}{l}595.25 \pm 112.68 \\
\text { seconds }\end{array}$ & $\begin{array}{l}518.73 \\
69.67 \\
\text { seconds }\end{array}$ & \\
\hline
\end{tabular}

[Table 3] shows the energy requirement in both Thiopentone and propofol groups revealed that energy required to induce muscular convulsions was statistically highly significant. More than 100 joules was needed in 17 sittings with Thiopentone.

Table 3:

\begin{tabular}{|l|l|l|l|}
\hline Study group & $\begin{array}{l}\text { Up to 50 } \\
\text { Joules }\end{array}$ & $\begin{array}{l}\mathbf{5 1}-\mathbf{1 0 0} \\
\text { joules }\end{array}$ & $\begin{array}{l}\text { More than } \\
\mathbf{1 0 0} \text { joules }\end{array}$ \\
\hline Thiopentone & 25 sittings & 09 sittings & 17 sittings \\
\hline Propofol & 26 sittings & 21 sittings & 05 sittings \\
\hline $\begin{array}{l}\text { P value (chi square } \\
\text { test) }\end{array}$ & $\mathrm{P}=0.03$ & & \\
\hline
\end{tabular}


[Table 4] shows the duration of muscular convulsions in both Thiopentone and propofol group the difference was insignificant $(20.76 \pm 9.09 \mathrm{v} / \mathrm{s} 24.44 \pm 9.84$ seconds; $\mathrm{P}=$ 0.053 Not Significant) but of shorter duration with thiopentone, but of adequate for therapeutic efficacy of MECT.

\section{Table 4:}

\begin{tabular}{|l|l|l|l|}
\hline Study group & Mean & $\begin{array}{l}\text { Standard } \\
\text { Deviation }\end{array}$ & $\mathbf{P}$ \\
\hline A & 20.76 & \pm 9.09 & $=0.052$ \\
B & 24.44 & \pm 9.84 & NS \\
\hline
\end{tabular}

[Table 5] shows that insignificant rise of serum potassium occurred in both groups of patient. Mean rise was higher for propofol group. $(0.55 \pm 0.35 \mathrm{v} / \mathrm{s} 0.68 \pm 0.68 \mathrm{MEq} / \mathrm{lit})$.

\begin{tabular}{|l|l|l|l|l|}
\hline Table 5: & & Pre-Ictal & Post-Ictal & $\begin{array}{l}\text { P-value for } \\
\text { increase }\end{array}$ \\
\hline \begin{tabular}{l|l|l|l|} 
Study \\
group
\end{tabular} & Mean & 4.06 & 4.59 & $=0.055$ \\
\hline A & $\begin{array}{l}\text { Standard } \\
\text { Deviation }\end{array}$ & \pm 0.50 & \pm 0.45 & \\
\hline & Mean & 4.02 & 4.74 & \\
\hline B & $\begin{array}{l}\text { Standard } \\
\text { Deviation }\end{array}$ & \pm 0.49 & \pm 0.52 & \\
\hline
\end{tabular}

[Table 6] showing that the in hemodynamic parameter and ECG recorded before anesthesia were within normal range in all patients included in the study.

\section{Table 6:}

\begin{tabular}{|l|l|l|l|}
\hline Parameter & Group A & Group B & Group C \\
\hline $\begin{array}{l}\text { MEAN PULSE } \\
\text { RATE (BPM) }\end{array}$ & 81.1 & 85.05 & 76.4 \\
\hline $\begin{array}{l}\text { MEAN SYSTOLIC } \\
\begin{array}{l}\text { BLOOD PRESSURE } \\
\text { (mmHg) }\end{array}\end{array}$ & 116.0 & 115.5 & 110.0 \\
\hline $\begin{array}{l}\text { MEAN DIASTOLIC } \\
\text { BLOOD (mmHg) }\end{array}$ & 66.5 & 71.0 & 66.0 \\
\hline ECG & WNL & WNL & WNL \\
\hline
\end{tabular}

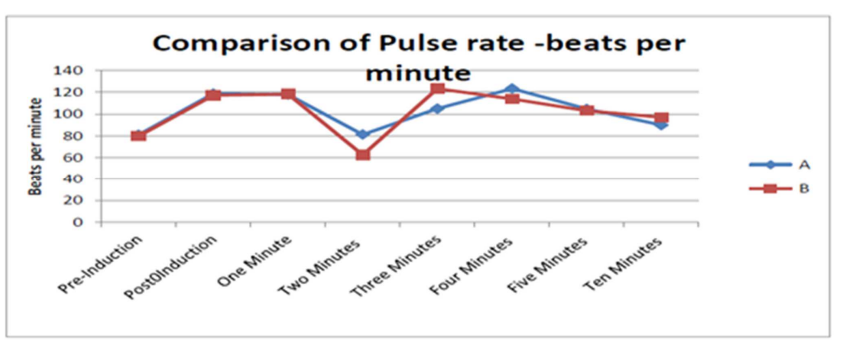

Figure 1:

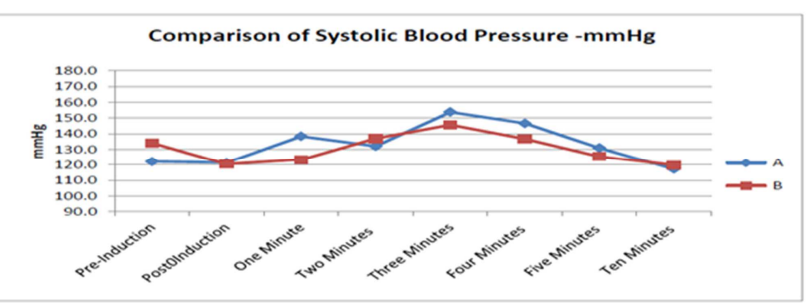

Figure 2:

[Figure 1-4] shows the changes in hemodynamic parameters before and after delivery of MECT. All patients had shown changes in hemodynamic parameter as described by Perin (1960). There are period of initial parasympathetic over activity followed by sympathetic over activity and finally the tone of both systems returned to baseline tone. Initial parasympathetic over activity occurring in first $15-20$ seconds cannot be recorded with usual monitoring equipments available.

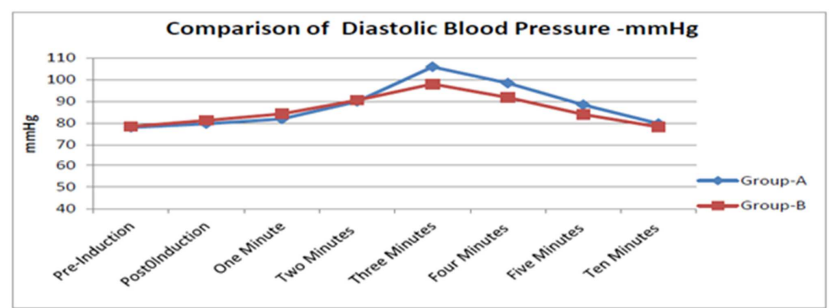

Figure 3:

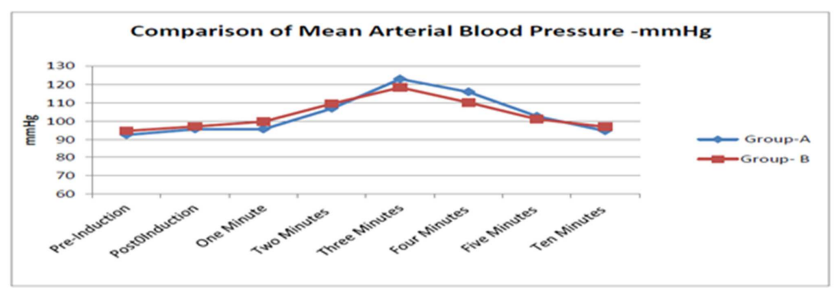

Figure 4:

[Table 7] shows the incidence of ECG changes observed. A brief period of bradycardia and lowering of systolic, diastolic and mean arterial blood pressure occurs during $2-4$ minute period that returned to baseline values within 30 minutes.

Table 7:
\begin{tabular}{|l|l|l|l|l|l|l|}
\hline & \multicolumn{9}{l|}{ Group A } & \multicolumn{2}{l|}{ Group B } \\
\hline Pre Induction & 37 & 13 & 1 & 44 & 6 & 2 \\
\hline Post Induction & 12 & 39 & 0 & 15 & 37 & 0 \\
\hline One Minute & 11 & 40 & 0 & 6 & 46 & 0 \\
\hline Two Minute & 17 & 16 & 18 & 29 & 0 & 23 \\
\hline Three Minute & 6 & 32 & 13 & 3 & 49 & 0 \\
\hline Four Minute & 3 & 48 & 0 & 7 & 45 & 0 \\
\hline Five Minute & 21 & 29 & 1 & 11 & 41 & 0 \\
\hline Ten Minute & 44 & 7 & 0 & 40 & 12 & 0 \\
\hline
\end{tabular}

[Table 8] shows the comparison of time to discharge in minutes using PADSS score. Patients who received propofol achieved safe PADSS score significantly earlier than those who received thiopentone.

\section{Table 8:}

\begin{tabular}{|l|l|l|l|}
\hline Study Group & Mean & $\begin{array}{l}\text { Standard } \\
\text { Deviation }\end{array}$ & P \\
\hline A & 22.55 & \pm 4.83 & $<0.01$ \\
\hline B & 16.44 & \pm 2.68 & \\
\hline
\end{tabular}

\section{Discussion}

MECT is a widely recognized and effective treatment for various psychiatric illnesses. Use of anesthetics reduced psychological trauma while succinyl choline chloride reduced the incidences of physical trauma (Wanderdel) and atropine supports the periods of parasympathetic over 
activity. ${ }^{[1]}$

In present study we used hypnotic doses of thiopentone, propofol and midazolam so that induction agent does not interfere with ECT induced cerebral seizures.

In present study induction, recovery time and time to discharge was shorter with propofol in comparison with thiopentone that was statistically significant. Induction was smooth with both thiopentone and propofol, however with midazolam in dose of $5 \mathrm{mg}$ did not produce satisfactory condition there was resistance to apply electrode and needed supplement with thiopentone.

Findings of present study do not tally with findings of many authors who reported on adequacy of sedation with midazolam for MECT \{Pratibha jain shah et al 2010, ${ }^{[3]}$ Arvind Arya, Manpreet Singh- , A.K Gurwara (2008); ${ }^{[4]}-\mathrm{N}$ Loimer, P Hoffman , H.R. Chaudhry (1992)\} ${ }^{[5]}$ All authors reported adequate sedation with midazolam.

Reason for getting inadequate sedation could be employment of lower doses in range of $0.09-0.1 \mathrm{mg} / \mathrm{kg}$ body weight, whereas Pratibha jain shah et al 2010(3), Arvind Arya, Manpreet Singh (2008), ${ }^{[4]}$ used midazolam in the dose of $0.2 \mathrm{mg} / \mathrm{kg}$.

N.Lomier, P. Hoffman and H.R Chaudhary (1992), ${ }^{[5]}$ compared midazolam anaesthesia with thiopentone plus succinyl choline, midazolam significantly reduces seizure duration that was not therapeutically desirable and concluded that midazolam anaesthesia offers no advantage over standard anaesthetic drugs for ECT with thiopentone and succinyl choline chloride.

In present study a short mean duration of muscle convulsion was observed with thiopentone i.e $20.76 \pm 9.09$ seconds as compared to propofol which was $24.44 \pm 9.84$ seconds $(\mathrm{P}=$ 0.052). The statistical comparison showed the change in duration of muscle seizures as not significant; but sufficient to produce therapeutically effective duration of muscle convulsion. Our findings correlate with Alok Kumar and others (2012) noted shorter mean seizure duration with thiopentone than propofol. ${ }^{[6]}$

Manpreet singh and others (2008), ${ }^{[6]}$ observed shortest duration with muscle seizure with midazolam(21.6 \pm 4.23 $\mathrm{sec})$, followed by propofol $(28.76 \pm 3.38 \mathrm{sec})$ and longest with thiopentone $(37.63 \pm 5.83 \mathrm{sec})$

In present study a small insignificant rise of 0.55 and 0.68 $\mathrm{mEq} / \mathrm{L}$ in thiopentone and propofol groups respectively was observed $(\mathrm{P}=0.055)$. Changes in serum potassium observed are inconsequential in healthy individuals while this change may assume clinically significant in patients with heart diseases and electrolyte imbalance. Bali IM and Agrawal R, ${ }^{[7,8]}$ Verma, Doshi, Kaur, G. D Shukla, Shrivastav; ${ }^{[13]}$ also found similar insignificant rise of serum potassium.

Changes in heart rate, systolic, diastolic, mean arterial pressure occurred with both induction agents and caused attenuation of hemodynamic response after MECT delivery but the rate and pressure responses were better suppressed with propofol than with thiopentone. Extent of attenuation of these acute cardiovascular responses is character of intravenous anaesthetics and co-administered drugs given to the patients. ${ }^{[1]}$ Mean Arterial Pressure (MAP) was similar in both groups at all times of observations. Kanako I wasaki et al (2002), ${ }^{[9]}$ did not observe significant change in MAP with two drugs that is propofol and thiopentone.
Significant difference was observed in present study in the mean time of recovery with thiopentone, was found to be $595.25 \pm 112.68$ seconds which was significantly higher than propofol 518.73 \pm 69.67 seconds $(\mathrm{P}<0.01)$.

Observations made in the present study corelate with the observations of Pratibha jain shah et al( 2010), ${ }^{[3]}$ Nadeem A Zaidi, Fauzia Khan(2000), ${ }^{[10]}$ Rolly G et al (1985), ${ }^{[1]}$ In year (2008)T M omprakash, mohd Inayat Ali, B Anand, M gouri devi, P surrender. ${ }^{[12]}$ All authors reported a shorter recovery time with propofol than with thiopentone or midazolam.

Incidence of postoperative nausea, vomiting, post ictal agitation was not observed.

Pratibha Jain Shah et al $2010,{ }^{[3]}$ reported occurrence of headache ,nausea, vomiting, pyrexia, Delerium, sensitivity, Thrombophlebitis, Apnea, tachycardia in her study as side effects and complications after anaesthesia.

\section{Conclusion}

Observations made in the present study allow us to conclude that

- Clear first choice as replacement of Methohexitone is propofol

- Thiopentone has its own pros and cons but can safely be used by experienced anesthesiologist.

- Methohexitone is still a Gold standard but it is difficult to procure

\section{References}

1. John L. Beyer, M.D., Andrew D. Krystal Mehul V. Mankad Richard D. Weiner - Clinical Manual of ECT, first edition 2010 ,chapters , introduction to ECT History of Electroconvulsive Therapy page - 3 to 8. Anaesthetics and other medications 81-96 ictal motor response 97104, ictal encephalographic response, $105-128$, Cardiovascular response 129-138.

2. Channapattana W. The origins of electroconvulsive therpy. J psychiatry association Thailand 2000;45:371-80

3. Pratibha Jain Shah, Kamta Prasad Dubey, Chhatarapal Watti, and Jaya Lalwani Effectiveness of thiopentone, propofol and Midazolam as an ideal intravenous anaesthetic agent for modified electroconvulsive therapy: A comparative study; Indian J Anaesth. 2010 Jul-Aug; 54(4): 296-301

4. Arvind Arya, Manpreet Singh, A.K Gurwara : Comparison of Thiopentone sodium, propofol and Midazolam for electrocomvulsive therapy: Journal anaesthesia clinical pharmacology:2008 24(3) pp 291294.

5. Loimer N1, Hofmann P, Chaudhry HR. 1992. Midazolam shortens seizure duration following electroconvulsive therapy; Jornal of Psychiatric research Apr;26(2):97-101

6. Alok Kumar, Devendra Kumar Sharma, Raghunandan Mani: A comparison of propofol and thiopentone for electroconvulsive therapy; Journal of anaesthesiology: Clinical Pharmacology 2012 Volume : 28 Issue : 3, 353-35

7. Bali and Dandi - British Journal of Anaesthesia 197547 (3) 398-401

8. Aggarwal R, Katyal S, Singh A, Kaul TK. Changes in serum potassium after electroconvulsive therapy. J Anaesthesia 2002;18;3539

9. Kanako Iwasaki, Atsuhiro Sakamoto, Takeshi Hoshino et al. Canadian Journal of Anaesthesia 49: 2002; 324-325

10. Nadeem A. Zaidi, Fauzia A. Khan Comparison of thiopentone Sodium and Propofol for Electro Convulsive therapy. Journal of Pakistan Medical Association 50:60, 2000

11. Rolly G, Versichelen L. Comparison of propofol and thiopentone for induction of anaesthesia in premedicated patients. Anaesthesia.1985;40: 945-48

12. TM Omprakash, Mohd Inayat Ali, B Anand, M Gowri Devi, P Surender Comparison of thiopentone sodium and propofol in ECT 
anaesthesia. Indian Journal of psychological Medicine 2008 Volume : 30 Issue $: 1: 48-51$
13. Varma, doshi, kaur. G.D. shukla. Shrivastav - Serum potassium changes with ECT -1982, Indian journal of psychiatry 24(2) 169-175

Copyright: () the author(s), publisher. Academia Anesthesiologica International is an Official Publication of "Society for Health Care \& Research Development". It is an open-access article distributed under the terms of the Creative Commons Attribution Non-Commercial License, which permits unrestricted non-commercial use, distribution, and reproduction in any medium, provided the original work is properly cited.

How to cite this article: Kasliwal H, Varshney VK, Neema MM. Evaluation of Thiopentone Sodium, Propofol and Midazolam for Modified Electro Convulsive Therapy. Acad. Anesthesiol. Int. 2019;4(1):33-37.

DOI: dx.doi.org/10.21276/aan.2019.4.1.8

Source of Support: Nil, Conflict of Interest: None declared. 